Мухамбеталиев К.М., Бердалина А.С., Аосжанова А.И.

Вопросы этнорекигиозной идентичности

Muhambetaliev K.M. Berdalina A.S., Doszhanova A.I.

\section{Questions of ethno-religious identity}

Мухамбеталиев К.М., Бердалина А.С., Аосжанова А.И.

Этно-діни сәйкестілік сұрақтары
В статье особый акцент слелан на анализе противоречивых проблем, связанных с возвращением казахов к своим этнорелигиозным истокам. Кроме того, рассматривается работа общественных и госуАарственных органов по делам религии по нейтрализации активной деятельности деструктивных религиозных организаций, действующих в Казахстане, а также положительные результаты их работы, направленные на преодоление и решение религиозных рисков в обществе с позиции межАународной, региональной и национальной безопасности.

В условиях глобализации мюбой этнос, нация, Аиаспора, боясь потеряться и бесследно исчезнуть в среде взаимосвязанных, взаимодействующих народов, всячески стремятся возродить и развить свою специфическую культуру и национальную религию.

Нынешнее возрождение национальных и религиозных корней тесно переплетено с проблемами преодоления существующих в обществе религиозных угроз и рисков, что требует от нынешних исследователей иного взгляда на проблему этнорелигиозной идентичности по-новому.

КАючевые слова: этнорелигия, этнорелигиозная идентичность, религиозный риск, региональная безопасность, национальная безопасность, Аеструктивные религиозные организации.

In the article a special emphasis on the analysis of controversial issues related to the return of Kazakhs to their ethno-religious origins. Also considered the work of public and state agencies on religious affairs to neutralize the vigorous activity of destructive religious organizations in Kazakhstan, as well as the positive results of their work to overcome the risks and the decision of the religious society from the perspective of international, regional and national security.

In the conditions of globalization any ethnos, nation, diaspore being afraid to get lost and without trace disappear in the environment of associate, interactive people, in every way aim to revive and develop the specific culture and national religion.

Present revival of national and religious roots closely casebound with the problems of overcoming of existing in society religious threats and risks, that requires from present researchers to give a glance on the problem of этнорелигиозной identity newly.

Keywords: etnoreligiya, ethno-religious identity, religious risk, regional security, national security, destructive religious organization.

Мақалада ұлттық, Аіни-мәдени біркелкілікті қалыптастыру мәселесі туысқан түркітілдес халықтар арасында ғасырлар бойы қалыптасқан тарихи қарым-қатынастарды қайтадан жандандыру негізінде қарастырылады.

Кез келген этнос жаһандану жағдайында ұлт және диаспора әсер етуші ұлттардың себебінен өзіне тән мәдениеттермен ұлттық Аіннің жоғалтып алу қауіпі бар.

Ағымдағы зерттеушілер жаңа жолмен этникалық, және Аіни сәйкестілік мәселесін қарауға, Аіни қауіп-қатерлер мен тәуекелдер қоғам еңсеру мәселелерімен ұлттық, және діни тамыры ағымдағы жанАануда жаңа көзқарастарды талап етеді.

Түйін сөздер: этно-діни сәйкестілік, діни қауіпсіздік, аймақтық, қауіпсіздік, ұлттық қауіпсіздік, деструктивті діни ұйым. 
УДК 2:172.3

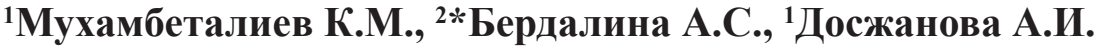

${ }^{1}$ Казахский университет международных отношений и международных языков им. Абылай хана, Республика Казахстан, г. Алматы

${ }^{2}$ Университет Туран, Республика Казахстан, г. Алматы *E-mail: assa.23@mail.ru

\section{ВОПРОСЫ ЭТНОРЕАИГИОЗНОЙ ИАЕНТИЧНОСТИ}

В контексте Послания Президента Республики Казахстан - Н.А. Назарбаева народу Казахстана «Стратегия «Казахстан 2050»: новый политический курс состоявшегося государства» рассмотрены вопросы сохранения, развития и утверждения собственной этнорелигии через призму специфической национальной культуры и менталитета народа.

В условиях глобализации любой этнос, нация, диаспора, боясь потеряться и бесследно исчезнуть в среде взаимосвязанных, взаимодействующих народов, всячески стремятся возродить и развить свою специфическую культуру и национальную религию (этнорелигию). Известно, что духовно-религиозная жизнь общества никогда не развивалась эффективно в условиях изоляции ее от остальных компонентов общественной жизни. Стремление возродить и развить свою этнокультуру и этнорелигию, «...постичь и сохранить свои истоки и корни, не должно происходить в условиях самоизоляции и устойчивой консервативности взглядов» [1], которые позволят сохранить собственную национальную идентичность, «свои характерные черты этническую окраску и, передаваясь из поколения, в поколение образуют т.н. этническую культуру, обладающую специфическим для нее стилем» [2]. Нынешнее возрождение национальных и религиозных корней тесно переплетено с проблемами преодоления существующих в обществе религиозных угроз и рисков, что требует от нынешних исследователей взглянуть на проблему этнорелигиозной идентичности по-новому. Известно, этнорелигиозная идентичность всегда носит национальный характер, у нее всегда присутсвуют элементы обычаев и традиций прошлой этнорелигии (напр., элементы шаманизма, тенгрианства и суфизма) и специфика национальной культуры и ценности. В годы советской власти, в условиях господства марксистсколенинской атеистической идеологии по отношению к религии, типа «религия есть опиум для народа» (Маркс) или «религия - род духовной сивухи» (Ленин), религия, как справедливо заметил Р. Кадыржанов, «функционировала как бы в подполье, но несла в себе огромный энергетический потенциал» [3]. Именно в них, имевших целостный национальный характер этнорелигиозных феноменах, сохранились существенные моменты многовековой истории и религиозных традиций, хотя они были, в 
известной степени, отрывочными, искаженными и фрагментарными.

Процесс становления независимости и суверенитета выдвинул на передний план проблемы укрепления и совершенствования национальной государственности Казахстана, идентификации культурно-религиозных ценностей казахского народа и его духовного потенциала. Достаточно быстрыми темпами, за каких-то два десятка лет, республика стала узнаваемой для мирового сообщества со своими геополитическими установками, четким определением путей своего дальнейшего развития, четким осознанием признаков специфической национальной культуры и этнорелигиозной идентичности (в смысле - субъективного представления и мировосприятия общества о себе). В связи с этим сегодня особенно актуальной стала не просто проблема возрождения своих исторических корней и духовных ценностей, приобретавшая особую идеологическую остроту в условиях мирового кризиса во всех сферах общественной жизни, но и обновление, обогащение и совершенствование национальной культуры и этнорелигиозных обычаев и традиций в соответствии с этими реалиями. Новые реалии принесли нашей стране не только рыночную экономику, геополитическое понимание того, что в мире происходит, но и формирование новых политических, юридических, нравственнно-этических, культурных, этнорелигиозных норм и принципов в решении важнейших вопросов государственной и национальной безопасности. К сожалению, Казахстан будучи сперва в составе Российской империи, а эатем в составе СССР около 300 лет, не имел возможности самостоятельно решать все эти вопросы. После приобретения независимости ему пришлось самостоятельно находить ответы на все эти вопросы, которые встали перед молодым государством. Тем более у него не было возможности брать пример у кого-либо из соседей, поскольку прктически все новые государства, образованные после распада СССР, так же, как Казахстан, барахтались в своих собственных проблемах, включая и ту Россию. В этих условиях приумножение новых культурных, этнорелигиозных ценностей, как неоднократно подчеркивал Первый Президент Казахстана Н.А. Назарбаев, сопровождалось систематическим внедрением в сознание верующих, особенно молодой ее части, концепции межнационального и межконфессионального единства и согласия, а также религиозной толерантности как государственной идеологии.
В связи с этим одним из острых и важных проблем казахстанского общества, ищущих свою этнорелигиозную идентичность, стало сложное и противоречивое переформатирование национально-религиозных ценностей как базовых. В основу формирования казахской государственности в XV веке была заложена этническая и этнорелигиозная идентичность казахских родов и племен. В состав Казахского ханства вошли исключительно племена и роды, принявшие мусульманство. Эти этнические группы имели «опыт совместного проживания и, детально зная друг друга, не были предрасположены к конфликту, поскольку огромное большинство населения не было заинтересовано в дестабилизации социально-политической обстановки» [4]. Поиск феномена этнорелигиозной идентичности для современного казахстанского общества важен, поскольку нахождение специфики национальной религии предков и ее растворение в составе современной этнорелигии являются по своей сути ключом духовно-культурного развития, восстановления национально-религиозных ценностей. Естественно, именно духовно-культурный уровень и нахождение этнорелигиозной идентичности являются теми факторами, которые могут защитить казахстанское общество от экономической, политической, религиозной, духовной катастрофы и оберечь его от межрелигиозных и межнациональных конфликтов, а также, в известной степени, оградить от религиозного экстремизма и терроризма как крайнего его проявления. Религиозный экстремизм и терроризм порождаются в такой благодатной среде, где верующие религиозно малограмотны (а это дает возможность деструктивным религиозным организациям манипулировать сознанием верующих, особенно молодых), социально отчуждены от общества (т.н. «социальные аутсайдеры» - выражение И. Тасмагамбетова), слабо ведется пропаганда этнорелигиозной идентичности. Все это в совокупности представляет собой непосредственную угрозу национальной безопасности страны. Однако подчеркнем, что такого рода экстремистские и террористские идеи в казахстанском обществе, традиционно никогда не признававшем всерьез идеи создания мусульманского «халифата» и «джихадизма», не имеют реальной идеологической почвы, хотя в некоторых местах они могут проявляться как единичные случаи. В основном, не эти сумасбродные идеи радикальных религиозных течений доминируют в обществе, а этнорелигиозная культура и ценности предков объективно считаются 
одним из важных факторов, составляющих основополагающий каркас современной этнорелигиозной идентичности. Этому способствует провозглашенная Казахстаном стратегическая цель государственной политики, изложенная в Конституции Казахстана и Законе РК «О религиозной деятельности и религиозных объединениях» [5], а также необходимые нормативные акты, где изложены основные принципы деятельности государства по отношению к религии и религиозным объединениям. В них указаны конкретные меры по усилению эффективности проводимых мероприятий, которые постоянно подкрепляются активной деятельностью государственных деятелей и представителями силовых структур. Для анализа сегодняшнего состояния этнорелигиозной идентичности казахского народа в многонациональном казахстанском обществе важно рассматривать следующие вопросы: в какой степени различные религиозные структуры вносят вклад в развитие не только собственной национальной религии и культуры, но и в развитие межрелигиозного и межнационального единства и согласия в республике; и в какой мере они ощущают на себе влияние различных культур и религиозных направлений.

Для казахстанского многонационального и многоконфессионального общества достижение единства и согласия возможно только в том случае, если верующие, независимо от их принадлежности к каким-либо направлениям религии, выстроят свое толерантное отношение и взаимопонимание к друг другу, благодаря которому любые разногласия и противоречия во взглядах будут решаться мирно, путем переговоров и диалога. Диалог должен способствовать не размежеванию позиций участников, а консолидации их точек зрения. А это предполагает поиск и нахождение того общего позитивного, что имеется в концепциях, обычаях, ритуалах и традициях каждой религии, что способствовало бы координации и сближению действий оппонентов. Значительную роль в этом процессе должны сыграть исламские и христианские религиозные организации, а также Ассамблея народов Казахстана, оказывающие огромное влияние на становление и развитие не только материальной и духовной культуры народов Казахстана, но и на возрождение этнорелигиозной идентичности основных религиозных направлений. В современных условиях поиск этнорелигиозной идентичности любого народа и ее становление, в том числе и казахского, опираются не только на нравственно-религиозные основы предков, оно также делает упор на общечеловеческие культурные и нравственно-религиозные ценности, что позволяет установить межконфессиональный и межрелигиозный диалог, соответственно найти компромисс между верующими для решения насущных экономических, политических и религиозных проблем.

В частности, в связи с активизацией своей деятельности таких негативных явлений, как религиозный экстремизм и религиозный терроризм, в известном смысле изменились контуры мирового порядка, эти деструктивные явления стали причиной формирования негативного отношения к ним практически всех стран мира. Сейчас их не ругают, не объявляют врагом номер один, разве что ленивые. Даже те страны - США, Великобритания, Франция, а также некоторые международные финансово-банковские организации, которые раньше к ним относились если не с пониманием, то со снисхождением, даже они стали смотреть на них, как на врагов не только своей страны, но и всего человечества. Эти геополитические изменения оказывают огромное влияние на весь ход мирового развития. В этом плане становление этнорелигиозной идентичности не означает слепое копирование нравственно-религиозных стандартов и норм поведения предков, а творческая переработка их с учетом богатых этнорелигиозных традиций, ценностей национальной культуры и менталитета казахского народа, который на протяжении нескольких столетий подтвердил свою жизнеспособность и способность к продуцированию многообразных социально-экономических, политико-правовых, историко-культурных ценностей. Формирование этнорелигиозной идентичности не позволит верующим некритическое восприятие того, что нам преподносят апостолы радикальных религиозных течений, со своей моделью исламского государства и религиозной морали арабского варианта, хотя какое может быть однозначное восприятие их, если сами арабы, проповедующие эти идеи, враждуют между собой не за чистоту религиозных принципов, а за политическую власть и за сферу влияния в мусульманских государствах. Религиозно-экстремистские действия, пропитанные террористическими установками, необратимо изменили взаимоотношения народов, их уклад жизни и отношение верующих к этим религиям. Несмотря на это, исторический опыт показывает, что практически невозможно слепо импортировать даже самые лучшие идеи, инновационные технологии и пересаживать их в другую культурно-нравст- 
венную, этнорелигиозную среду, поскольку они в новой среде, в силу их растущей изоляции от необходимого социально-религиозного контекста плохо приживаются, что не дает должного эффекта. Тем более, это справедливо в отношении концепции радикальных религиозных систем и попытки импортировать идею создания «исламского государства» во всех мусульманских странах. Хотя эта идея многими верующими рассматривается как своеобразная религиозная агитка, профанация, направленная на дискредитацию идеи исламской религии и чистоту его помыслов, однако они будоражат умы многих. Неслучайно, поверив призыву через интернет о необходимости оказания помощи мусульманам Сирии и Ирака, из Казахстана отправились около 300 человек, чтобы защитить «зеленый флага ислама», «Исламское государство Ирака и Леванта», стариков, женщин и детей этих стран. Можно подумать, что в этих странах остались очень близкие, дорогие родственники, ради которых можно пожертвовать своей жизнью.

Идея объединения всех мусульман под общим исламским флагом сама по себе не нова. Во второй половине XIX в Казахстане получила распространение идея «панисламизма», проповедниками которой были известные казахские теологи и мыслители XIX века - М.Ж. Копеев и Кашаф-ут-Дин. Они, прекрасно понимая, что мусульманские народы, живущие в Российской империи, своими силами не добьются независимости, полагали объединить усилия всех мусульман России для достижения этой цели. В то время эта идея должна была выполнять объединительную функцию в борьбе за независимость. Несмотря на благие намерения, эта идея была политической утопией. Сейчас же, когда чужие апостолы хотят решить свою проблему прихода к власти в чужой стране и религиозно, и политически малограмотных молодых людей - эта идея становится источником раскола мусульман. Она становится абсурдным призывом к радикальным действиям, поскольку они стараются объединить фундаменталистские основы раннего ислама, с их идеей «джихад» против не ставших в истинном смысле еще мусульманами народов, включая мусульман местной традиционной этнорелигии, не признающих позиции «джихадистов». Тем более чуждым выглядит распространяемая идея идеологов «Исламского государства», которые придумали новый вид джихадизма - т.н. «брачный джихад», или как иногда их называют «половой джихад», суть которого заключается в том, что «женщин воюющей страны, попав- ших в плен, или женщин других государств, обманом оказавшихся в Сирии и Ираке, насильно вынуждают обслуживать прихоти мусульманских сарбазов вплоть до половых связей, причем считается, что чем больше они обслуживают сарбазов бесплатно, тем лучше, поскольку они делают богоугодное дело» [6. Свободный перевод автора - К.М.]. Как можно без ужаса смотреть на такое кощунственное извращение сути исламской религии, заставляющее женщин, т.н. «не истинных мусульманок», к проституции, причем именем ислама. Чтобы такого рода псевдоидеи радикальных религиозных сект, имеющих место в Сирии и Ираке, не докатились и до нашей страны, необходимо восстанавливать и культивировать собственные этнорелигиозные ценности. В таком плане религиозная идентичность станет объединяющим фактором, стимулом, источником развития духовных, культурно-нравственных основ современного казахстанского общества. Поиск и становление этнорелигиозной идентичности помог бы народу находить то духовное начало, нравственное поле своего существования, благодаря которому он имеет собственное «Я», сохраняет свои корни и специфичность, независимо от его воспитания и образования. Поэтому человек, независимо от его религиозных приоритетов, должен быть представителем конкретного народа, носителем его культурного, духовно-религиозного кода. Тем более, восстановление духовно-религиозного кода важно как установка, позволяющая ему выйти на качественно новый уровень, сохранив условия для свободного развития этнорелигиозного наследия, обычаев и традиций всех, кто проживает в Казахстане. В этом плане процесс обретения суверенитета и независимости Казахстаном положил начало формированию современного духовного, религиозно-нравственного облика казахстанского общества. Эффективность работы нашего государства была связана с реализацией концепций, изложенных в Программах «Казахстан-2030» и «Казахстан-2050 - программа сотоявшегося государства», которые показали всему миру, что сегодня в Казахстане сформировалась своеобразная «казахстанская модель межэтнических и межконфессиональных отношений», где основной упор делается на формирование благоприятных условий для дальнейшей консолидации общества. В этой связи принятая в 2008 году «Доктрина национального единства» и принятый в 2011 году Закон РК «О религиозной деятельности и религиозных объединениях» стали значительным общественным явлением, 
сыгравшим особую объединяющую роль и способствовшим консолидации казахстанского общества. Однако, все эти задачи можно реализовать при достаточно высоком уровне духовной зрелости людей. Вот почему в наше время резко возрос интерес к изучению внутреннего мира человека, его социально-религиозных, нравственных и духовных корней, его связи с историческим прошлым. Это, естественно, предполагает возрождение и развитие национальной культуры и этнорелигиозной идентичности и толерантности в казахстанском обществе через систему образования и воспитания, корректное освещение проблем религии в СМИ, повышение этнорелигиозной культуры казахстанцев. В свое время С. Хантингтон в журнале «Калейдоскоп», подчеркивая идентичность как явление взрывоопасное, писал: «идентичность на уровне цивилизации будет становиться все более важной,... потому взрывоопасной и меняющейся концепцией 90-х.» [7].

Действительно, современный ход социальноэкономического развития, а также происходящие в мире и в Казахстане геополитические процессы разрушили не просто старые нравственно-религиозные стереотипы и соответствующие им структурные образования, не предлагая взамен равноценных новых, но и заложил начало таким негативным явлениям, как социально-экономическая нестабильность, политико-правовая дезориентация и религиозно-нравственная деморализация казахстанского общества. «Происходит искусственное конструирование и распространение альтернативных версий истории традиционных конфессии, которые призваны манипулировать историческим сознанием народа, формируя псевдонациональное самосознание» [8]. Поэтому сегодня важно выяснить, действительно ли предки казахов издавна обладали общим для этноса этнорелигиозным сознанием, основанным на менталитете казахского народа, что само по себе является важнейшим теоретическим вопросом, которого необходимо глубоко и всесторонне изучить. Разработка концепций по формированию и становлению этнорелигиозного единства предполагает всесторонний анализ специфики казахстанского общества, важным составляющим которого выступает религиозная символика. Так, мавзолеи Ходжи Ахмеда Ясави, Бекет ата и др. как этнорелигиозные символы казахов являются наглядным материальным доказательством того, что все казахи обладали общим религиозным самосознанием и духовными ценностями. И высказывания некоторых религиозных деятелей, ратующих за чистоту ислама и призывающих к разрушению этих национальных святынь, их попытка стереть из памяти народа их национальную гордость и духовные ценности чреваты трагическими последствиями. Естественно, мусульманское наследие в этнорелигиозной культуре казахов объективно имеет место, но с национальной спецификой, т.е. ислам как элемент своей культуры вобрал в себя некоторые моменты шаманизма и тенгрианства. Еще одной важной составляющей структуры этнорелигиозной идентичности являются проблемы, связанные с межконфессиональным согласием и толерантностью.

Этнорелигиозная концепция, в основе которой лежали принципы единства, взаимопонимания и толерантности, взяла курс на воспитание светского человека, знающего свою национальную культуру и религию, приверженного идеалам мира, толерантности и способного к конструктивному диалогу. В то далекое и непростое время представителей разных конфессий и этносов, «связали общая судьба и история, вместе строили фундамент нашей общей Отчизны», подчеркивал Президент страны Н.А. Назарбаев, открывая 15-летнюю юбилейную сессию АНК. Благодаря реализации этого курса сегодня Казахстан достиг определенного прогресса в плане преодоления дестабилизационной ситуации, избежав политизации межрелигиозных отношений, направив имевшие место одиночные конфликтные случаи в мирное русло.

\section{Литература}

1 Утельбаев К.Т. Этнокультурный фактор - истоки и реалии // В сб. «Глобализация и социально-гуманитарные проблемы современного Казахстана». - Алматы, 2007. - С.89.

2 Бромлей Ю.В. Очерки теории этноса. - М., 1983, - С. 45.

3 Кадыржанов К.Казахстанская модель этнополитики. - Алматы, 2002, - С.69.

4 Козырев Т.А. Проблемы обеспечения духовной безопасности Казахстанского общества // В сб.матер. междунар. конф. 9 марта 2013 г. «Свобода вероисповедания в Казахстане». - Астана, 2013. - С. 81-82.

5 Закон РК от 11.10. 2011 г. № 483-1V «О религиозной деятельности и религиозных объединениях». - Алматы, 2011.

6 Мыңжасар Б. Жихад және нәпсі. Социал-демократ \№ 1(48) 15 қаңтар 2015.

7 Хантингтон С. Столкновение цивилизации // «Калейдоскоп». - 1985. 
8 Лама Шариф Қ.Қ. Свобода вероисповедания в РК: теория и практика.

\section{References}

1 Utelbaev K.T. Ethno-cultural factor - the origins and realities // In the collection. "Globalization and the social and humanitarian problems of modern Kazakhstan". - Almaty, 2007. - S. 89.

2 Bromley Y. Essays on the theory etnosa. - M., 1983, - P.45.

3 Kadyrzhanov K. Kazahstanskaya model of ethnic policy. - Almaty, 2002,- P.69.

4 Kozyrev T.A. Problems of ensuring spiritual security of the Kazakhstan society. \I In sb. mater. mezhnar. konf. 9 March 2013. "Freedom of religion in Kazakhstan" Astana. 2013. - S. 81-82.

5 The Law of the Republic of Kazakhstan on 11.10. 2011 g. № 483-1V «On religious activity and religious associations”. Almaty, 2011.

6 Mynzhasar B. Zhihad zhane nəpsi // Social Democrat. № 1 (48). - 15 kantar 2015.

7 Hantington S. Clash of civilizations // «Kaleidoscope». - 1985.

8 Lama Sharif K.K. Svoboda religion in Kazakhstan: theory and practice. 